DOI:10.26080/krrmkozl.2013.2.191

\title{
Két 16. századi fémfonalas párta anyagvizsgálata, készítés-technikája és restaurálása
}

\author{
LENGYEL BOGLÁRKA \\ Magyar Nemzeti Múzeum \\ H-1088 Budapest, Múzeum krt. 14-16., lenboglar@gmail.com
}

Lengyel, B.: Material testing, production-technology and restoration of two 16th century corollas made with metal thread

Abstract: During the restoration of two 16th century corollas made with metal thread, the aim was not only to conserve these artifacts but also to make a documentation according to which a reconstruction of the corollas can be made in the future.

We have compared these corollas (one of which was found in Tapsony-Terebezd, and the other one is from an unknown locality), according to their materials and production-technologies. In the course of the comparison, it turned out that the metal thread of the artifacts is yellow brass foil twined around the silk inner thread. The use of these materials together is unique. The synthesis of the corollas' metal threads are quite similar to each others.

Keywords: corolla, metal thread, fake gold thread, lace, islog, sequin

\section{Bevezetés}

Két párta lelet restaurálásának befejezésére kértek fel. Azt gondolom, hogy a restaurálás során tett készítéstechnikai megfigyelések fontosak lehetnek a pártákkal és a történeti viselettel foglalkozó régészek számára. Bár a párták rossz állapotúak, töredékesek, mégis kidolgozásuk miatt érdekesek. Remélem, hogy részletes leírásuk segítheti a később előkerülő párták feldolgozását analógiaként. Esetleg fordítva, egyéb párták segíthetnek az alábbiakban közöltek bizonytalan részeit még pontosabban rekonstruálni.

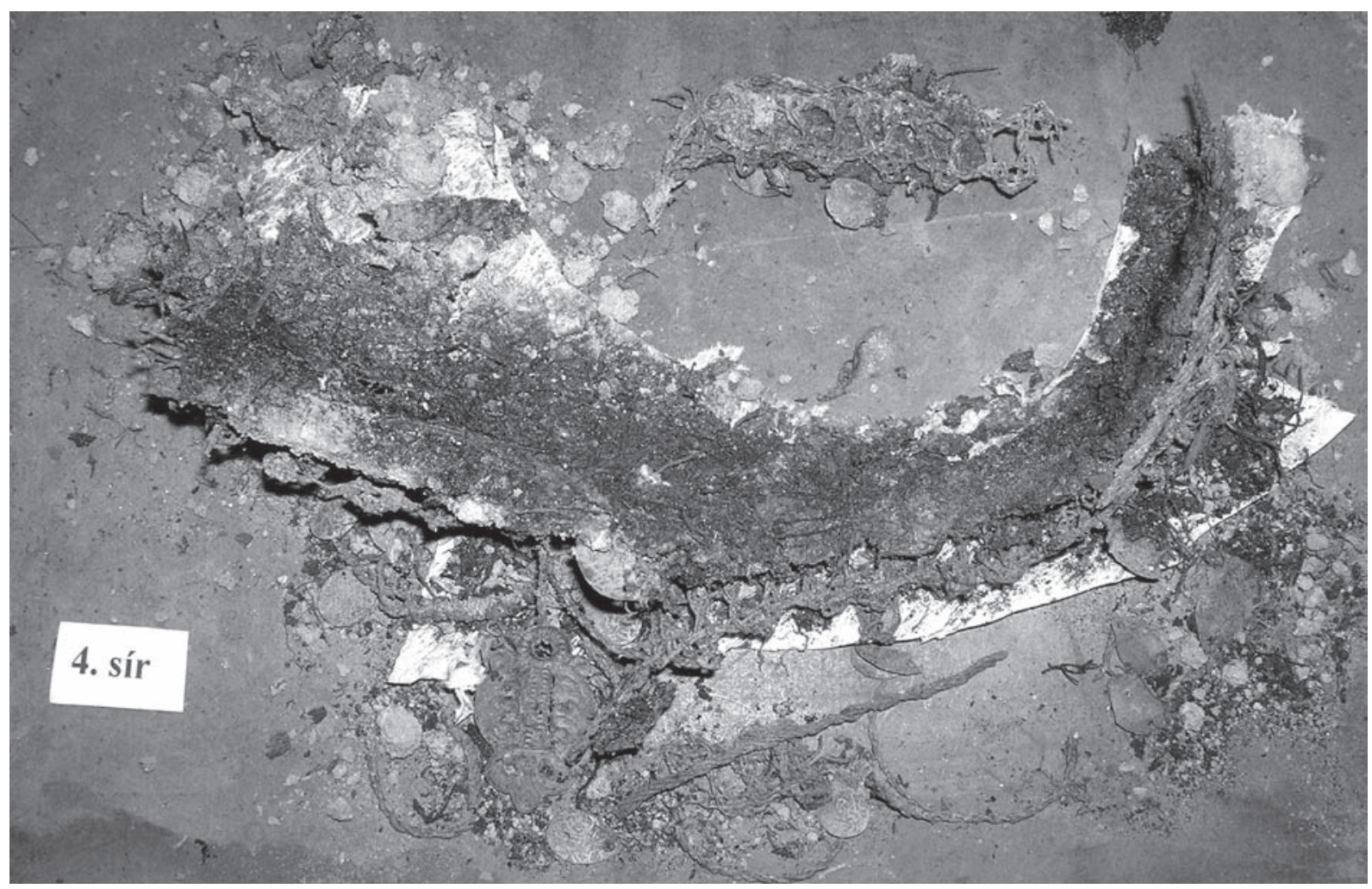

1. kép: Terebezd 4. számú sír pártája restaurálás előtt 
A két leletben közös, hogy a csipkék fémfonalakból készültek, amelyeket flitterek díszítenek. Hasonló a fonalfelépítésük és készítés-technikájuk. Az egyik Tapsony-Terebezd 4. számú sír pártája, a másik ismeretlen lelőhely, szám nélküli sír pártája. ${ }^{1}$

A fémfonalas párta leletek restaurálás szempontjából is sajátos helyzetűek, mert összetett anyaguk miatt egyszerre igényelnek textiles és fémes szakismeretet. Régészeti fémrestaurátorként ezért tartottam szükségesnek több textiles szakember (textil restaurátor és csipke szakértő) bevonását a munkába.

Úgy gondolom, talán a restaurálás alatt nyílik leginkább lehetőség a mútárgy mélyebb megismerésére.

A bontás, tisztítás hosszadalmas folyamata alatt felfedezhetőek a párta készítése során alkalmazott különböző fogások. Ezen keresztül bepillanthatunk abba, hogy a mester milyen módszer szerint dolgozott.

Az anyagvizsgálatok segítségével pedig a tárgyat alkotó anyagok összetételét ismerhetjük meg.

Mindezek együttes alkalmazásával - a restaurálás után - képet alkothatunk arról, hogy milyen is lehetett a két párta a viselés korában. Ennél még pontosabb képet az eredeti készítés-technikával megalkotott rekonstrukció nyújthat.

\section{A párták leírása}

A Terebezd 4. számú sír pártájának adatai és leírása:

anyaga: sárgaréz, bőr, textil, csont, üveg

hossza: $31 \mathrm{~cm}$, szélessége: $3,5 \mathrm{~cm}$

csipke szélessége: $2 \mathrm{~cm}$

fémfonal átmérő: $0,4 \mathrm{~mm}$

fémfonal szalag szélessége: 0,8-0,9 mm

flitter: $8 \times 12 \mathrm{~mm}, 9 \times 13 \mathrm{~mm}, 85 \mathrm{db}$

üveggyöngy: $25 \mathrm{db}$

csontgyöngy: $17 \mathrm{db}$

csavart üveggyöngy: $6 \mathrm{db}$

A párta fémfonalakból készített vert csipke², az alapja bőr és textil volt. Csont-, és üveggyöngyökkel, valamint vékony lemezből készült csepp alakú flitterekkel (islógok, ragyogók) díszítették. A flittereket két szálból sodrott fémfonalakon kis drótkarikákkal rögzítették. A párta közepén egy nagyobb méretű tulipánt vagy liliomot ábrázoló vékony lemezdísz található.

A félköríves forma és a koponya homlokrészének elszíneződése alapján - amelyet a párta fém részeinek korróziója okozott - a párta ún. előpárta, mely a homlokot díszítette. A fej hátsó részén a fej kerületéhez volt állítható, feltételezhető, hogy szalagokkal kötötték meg, de ezekből nem maradt meg semmi. Mojzsis Dóra csoportosítását ${ }^{3}$ alapul véve díszítése szerint a fémszáldíszes-gyöngyös párták csoportjába tartozik. Gábor Gabriella ${ }^{4}$ és Selmeczi László 5 a keskeny csipkedíszes pártákat a szalagpárták csoportjába sorolják.

Analógiának tekinthető a nagylózsi K/9 kislánysír ${ }^{6}$ pártája a középdísz kivételével és a nagylózsi K/7-es sírból ${ }^{7}$ származó párta.

A „Szám nélküli” sír párta adatai és leírása: megnevezése: fémfonalas, gyöngyös, flitteres pártaöv anyaga: sárgaréz, bőr, textil hossza: $43 \mathrm{~cm}$, szélessége: $6 \mathrm{~cm}$ fémfonal átmérő: szimpla: 0,4 mm, sodrott: $1 \mathrm{~mm}$, duplán sodrott: $5 \mathrm{~mm}$ fémfonál szalag szélesség: 0,8-0,9 mm, duplán sodrott: $0,5 \mathrm{~mm}$ gyöngyök: kicsi: kb. $3 \times 4$ mm 28 db, nagy: kb. $5 \times 7$ mm, 14 db, 2db virág alakú flitter: $8 \times 12$ mm, összesen: 54 db

1 A somogysámsoni ásatás (ásatásvezető dr. Költő László) leletei közül kilenc sír pártatöredékei kerültek restaurálásra. A párták restaurálását Bakayné Perjés Judit kezdte el, így a tárgyak beazonosítása, állapotfelmérése és a tárgyak kezelés előtti leírása az általa készített dokumentációk alapján készült. A restaurálást nem fejezhette be, váratlan halála miatt. A munkát abban a szemléletben igyekeztem folytatni és méltóképp befejezni, ahogyan Ő elkezdte, hálám jeléül a Tőle tanultaknak.

A párták között két szám nélküli sír pártatöredékei voltak. Az épebb, szélesebb pártatöredék (a restaurálási dokumentációban a megkülönböztetés miatt pártaövnek nevezett) nem a somogysámsoni leletegyüttes része. Ez restaurálás után az átadáskor derült ki. Ameddig nem derül fény a párta lelőhelyére, addig Ismeretlen lelöhely, szám nélküli sír pártájaként „azonosítom”.

2 A vert csipke: A valódi csipke egyik fajtája, elkészítése bonyolult. Alapműveletei: fonás, csavarás, szövés. Legkevesebb négy fonal szükséges a készítéséhez. Szerszámai: négyszögletes vagy henger alakú párna, verőpálcák (orsók), a mintarajz és a vetéseket rögzítő gombostük. Magyar Nagylexikon, 18. kötet 384.

3 Mojzsis 1984.

4 Gábor 1996

5 Selmeczi 2006

6 Mojzsis 1984. 202. 6. ábra 2. kép

7 Mojzsis 1984. 12. ábra 3. kép 


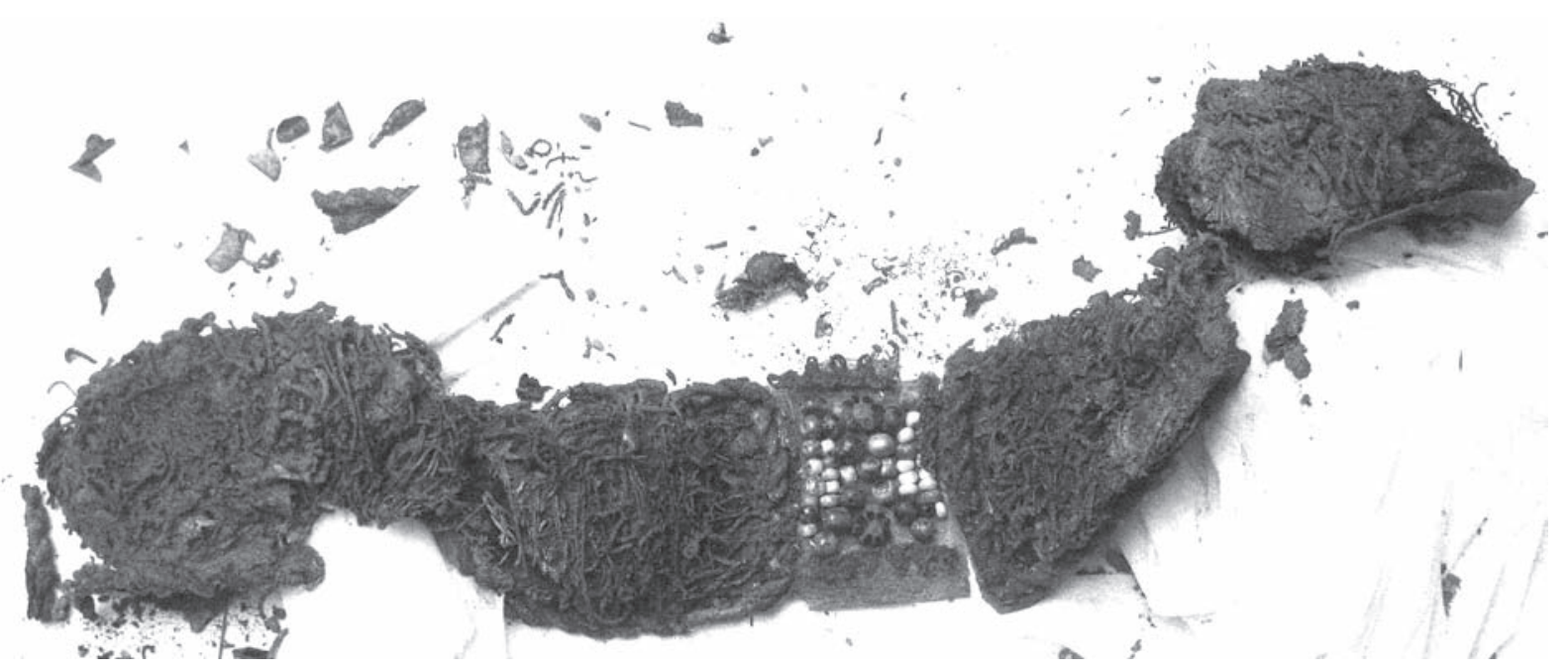

2. kép: „Szám nélküli” sír pártája restaurálás előtt

A párta homlok-közepi részét színes üveggyöngyök díszítik, négyszögletes formába rendezve. Középen öszszeérő, két háromszög alakba elhelyezve, alatta és felette egy-egy piros szirmú virág alakú gyönggyel. A gyöngyöket fémfonalból készült vert-csipke és két szálból sodrott fémfonal keretezi négyszög alakban.

Kétoldalt a vastag, kidomborodó pártarészt fémfonalakból készült hálócsipke borítja. A hálócsipke szálai között két szálból sodrott fémfonalakon csepp alakú vékony lemezből készült flitterek találhatók. Szegélydíszként fémfonalakból készült vastag zsinór keretezi a két kidomborodó téglalap alakú hálócsipkés részt.

A párta alapja textil és bőr, a kidomborodó részt növényi rostokkal tömték, merevítették.

Ez a pártatípus rendkívül ritka, ezért különösen érdekes, hogy szintén Somogy megye egy másik ásatásából, a Kaposvárt elkerülő 61 . számú úti temető 836 . számú sírjából egy hasonló párta került elő.

\section{Anyagvizsgálatok}

Az anyagvizsgálatok két fő célja a szerves anyagok (textil, bőr leletek) meghatározása és a szervetlen (fém) leletek anyagösszetételének meghatározása.

\section{Mikroszkópos vizsgálat, szerves bélfonalak meghatározása}

A fémfonalak rossz állapotúak, sok helyen a bélfonal egyáltalán nem maradt meg, csak a korrodált fémfólia, ami a bélfonalat borította. A bélfonalak legtöbb helyen a fém korróziós termékeivel együtt őrződtek meg, kiszáradtak, morzsolódnak.

Az elemi szálakra való bontás tárgylemezen, optikai mikroszkóp alatt történt. A szálak vizsgálatát - glicerinbe ágyazás után - polarizációs mikroszkóp alatt, 20x-os és 40X-es nagyításban lehetett elvégezni. ${ }^{9} \mathrm{~A}$ bélfonalak minden esetben fehér színúek voltak, zöldes elszíneződéssel.

1. minta: Tapsony-Terebezd 4. számú sír pártája: flittertartó sodrott szál. Felületén S irányba tekeredő fémszalag, bélfonala: selyem, $\mathrm{S}$ sodratú.

2. minta: Tapsony-Terebezd 4. számú sír pártája: a csipke bélfonala. Felületén S irányba tekeredő fémszalag, bélfonala: selyem, $\mathrm{S}$ sodratú.

3. minta: „Szám nélküli” sír pártája: a csipkét alátámasztó textil. Vászonkötésű. Anyaga - a szálak túlzott roncsolódása miatt - nem határozható meg.

4. minta: „Szám nélküli" sír pártája: flittertartó sodrott szál. Felületén S irányba tekeredő fémszalag, a fonal S2 Z ${ }^{10}$ sodratú, bélfonala: selyem, $\mathrm{S}$ sodratú

5. minta: „Szám nélküli” sír pártája: hálócsipke fonala. Felületén S irányban tekeredő fémszalag, bélfonala: selyem, $\mathrm{S}$ sodratú.

6. minta: „Szám nélküli" sír pártája: keretező zsinór. Felületén S irányba tekeredő fémszalag, a fonal S2 Z sodratú, bélfonala: selyem, $\mathrm{S}$ sodratú.

8 Bárdos 1987. 17-18., Selmeczi 2006. 44-45.

9 A fémfonalak és textilszálak anyagvizsgálatát Juhász Andrea textil-restaurátor végezte.

10 S2 Z $\rightarrow$ kétágú = két $S$ sodratú fémfonalból készített 1 Z sodratú fonal. 


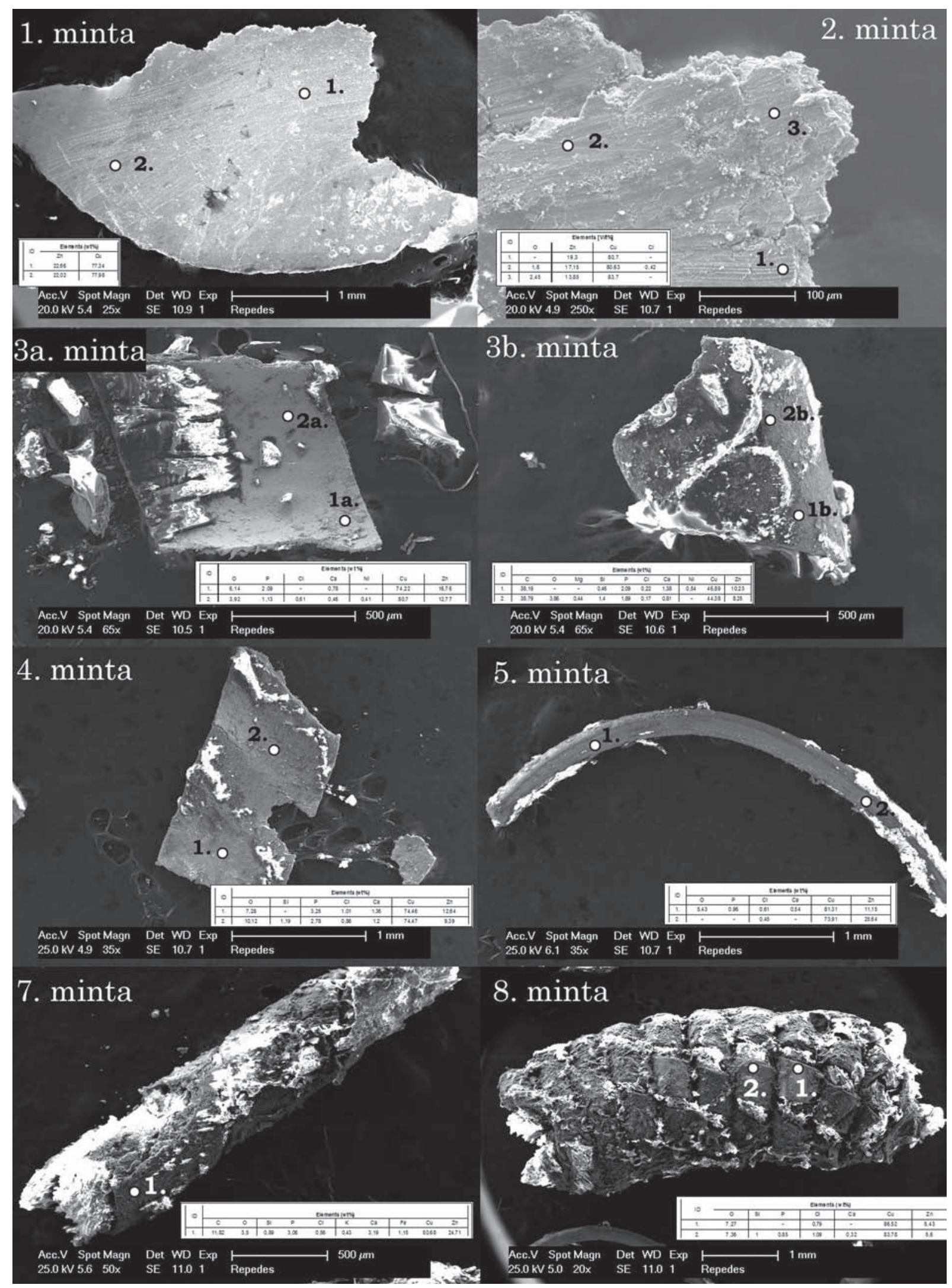




\section{Fémfonalak elektronmikroszkópos anyagvizsgálata és elektronsugaras mikroanalízis (SEM+EDS)}

A szálak korrodáltak, a flitterek jobb állapotúak. 8 mintát készítettem, 2 flitter, 6 különböző szál, illetve zsinór. Az egyik vékony szálnál és a zsinórnál feltételeztük, hogy ezüstözhették. A flittereket talán aranyozták. Ennek eldöntésére elektronmikroszkópos vizsgálatot és elektronsugaras mikroanalízist (SEM+EDS) végeztünk. ${ }^{11}$ A 8 mintából 7 esetben volt értékelhető eredmény. Az egyik vékony szál annyira korrodált volt, hogy a kapott eredmény bizonytalan (tiszta fémfelület hiányában egy ponton sem lehetett fémösszetételt mérni). A többi esetben két-három ponton mértünk fémösszetételt.

1. minta:Tapsony-Terebezd 4. számú sír, párta: flitter.

A korrodált, szennyezett réteg eltávolítása után a tiszta fémfelület sárgásan csillogott. Kérdés, hogy sárgaréz vagy aranyozott a flitter. A legjobb állapotú minta.

A flittertöredék két pontján mértünk, mindkét eredmény alapján sárgaréz:

1. pont: $77 \%$ réz és $23 \%$ cink.

2. pont: $78 \%$ réz és $22 \%$ cink.

2. minta: „Szám nélküli” sír, párta- flitter.

A korrodált szennyezett réteg eltávolítása után a tiszta fémfelület egy részen sárgásan, másik részen vörösesen csillogott. Feltételezhető, hogy aranyozott vörösrézből készült a flitter. Nagyon korrodált, rossz állapotú a minta, a tiszta fémfelület csak mikroszkóp 40x-es nagyításában látható.

A flittertöredék három pontján mértünk, mindhárom eredmény alapján sárgaréz:

1. pont: $80 \%$ réz és $19 \%$ cink.

2. pont: $80 \%$ réz és $17 \%$ cink.

3. pont: $83 \%$ réz és $13 \%$ cink.

Kis mennyiségben oxigén és klór is jelen van, ez abból adódik, hogy a felület nem „fémtiszta”, hanem a korróziós termékek is jelen vannak. A réz-cink arány néhány százalékos eltérése adódhat abból, hogy az ötvözetben nem egyenletes az eloszlás.

3. minta: Tapsony-Terebezd 4. számú sír, párta: bélfonal nélküli fémszál.

A korrodált szennyezett réteg eltávolítása után a tiszta fémfelület ezüstösen csillogott. Feltételezhető, hogy a bélfonalra tekert fólia ezüst vagy ezüstözött lehet. Nagyon korrodált, rossz állapotú a minta, a tiszta fémfelület csak mikroszkóp 40x-es nagyításában látható.

A bélfonalra tekert fólia nagymértékben korrodált, ezért két töredék két-két pontján mértünk, mert a felület szennyezett volt. Minden eredmény alapján sárgaréz:

1a. pont: $74 \%$ réz és $17 \%$ cink, $6 \%$ oxigén, ez kb. 79-21\%-os ötvözetnek felel meg.

2a. pont: $81 \%$ réz és $13 \%$ cink, $4 \%$ oxigén, ez kb. $84-16 \%$-os ötvözetnek felel meg.

1b. pont: $47 \%$ réz és $10 \%$ cink, $38 \%$ szén, ez kb. $83-17 \%$-os ötvözetnek felel meg.

2b. pont: $44 \%$ réz és $8 \%$ cink, 39\% szén, ez kb. $85-15 \%$-os ötvözetnek felel meg.

A nagy mennyiségben jelen lévő szén szerves szennyeződésre utal. Az oxigén mellett, foszfor kalcium és minimális klór is jelen van, ez abból adódik, hogy a mérési pont felülete nem „fémtiszta”, hanem a korróziós termékek is jelen vannak.

4. minta: Tapsony-Terebezd 4. számú sír, párta: sodrott fémszál bélfonallal, amelyen a flitter függ.

Nagyon korrodált, rossz állapotú a minta, a tiszta fémfelület csak mikroszkóp 40x-es nagyításában látható.

A fémszál fóliájának két pontján mértünk, mindkét eredmény alapján sárgaréz:

1. pont: $74 \%$ réz és $13 \%$ cink, $7 \%$ oxigén, ez kb. $85-15 \%$-os ötvözetnek felel meg.

2. pont: $74 \%$ réz és $9 \%$ cink, $10 \%$ oxigén, ez kb. $89-11 \%$-os ötvözetnek felel meg.

A nagyobb mennyiségben jelen lévő oxigén, valamilyen rézoxid vegyület lehet, foszfor kalcium és minimális klór és szilícium abból adódhat, hogy a mérési pont felülete nem „fémtiszta", hanem a földes-korróziós termékek is jelen vannak.

5. minta: „Szám nélküli” sír: flittertartó karika.

A megtisztított felületen a drót, amiből a karika készült ezüstösen csillogott, feltételezhető, hogy ezüstből készült. Jó állapotú a minta, szabad szemmel, mikroszkóp nélkül is látható a fémfelület.

A drótszál két pontján mértünk, mindkét eredmény alapján sárgaréz:

1. pont: $81 \%$ réz és $11 \%$ cink, $5 \%$ oxigén, ez kb. $88-12 \%$-os ötvözetnek felel meg.

2. pont: $76 \%$ réz és $24 \%$ cink.

Az oxigén valamilyen réz-oxid vegyületre utal.

11 A elektronmikroszkópos anyagvizsgálat és elektronsugaras mikroanalízis (SEM+EDS) vizsgálatokat Thiele Ádám végezte a BME Anyagtudományi Tanszékén. 
6. minta: „Szám nélküli” sír pártájának sodrott fémszála, amin a flitter függ.

A 4. sír pártájának flittert tartó fonalával hasonló, arra kerestünk választ, hogy csak formailag hasonló, vagy anyagösszetétel szempontjából is. Az elektronmikroszkóppal vizsgált szál annyira korrodált volt, hogy a kapott eredmény nem értelmezhető, tiszta fémfelület hiányában egy ponton sem lehetett fémösszetételt mérni.

7. minta: „Szám nélküli” sír: hálócsipke szimpla fémfonala.

A korrodált szennyezett réteg eltávolítása után a felület fémesen csillogott. Feltételezhető, hogy a bélfonalra tekert fólia ezüst vagy ezüstözött lehet.

A Tapsony-Terebezd 4. számú sír pártájának szimpla szálához hasonló, azzal a különbséggel, hogy ennél a bélfonal is megmaradt (a 3. mintával).

A nagyon korrodált, rossz állapotú mintán, a tiszta fémfelület csak mikroszkóp 40x-es nagyításában látható.

A szál annyira korrodált volt, hogy csak egy ponton találtunk tiszta fém felületet, ezért csak egy mérés történt. A réz-cink aránya sárgarézre utal, a magas széntartalom szerves szennyeződésre. Az oxigén, foszfor, kalcium földes-meszes korróziós rétegre utalhat.

1. pont: $51 \%$ réz és $26 \%$ cink, $12 \%$ szén, 3,5\% oxigén, ez kb. 66-34\%-os ötvözetnek felel meg.

8. minta: „Szám nélküli” sír: keretező szegélye, duplán sodrott zsinórja.

Nagyon korrodált, rossz állapotú a minta, a tiszta fémfelület csak mikroszkóp 40x-es nagyításában látható.

A zsinór két pontján mértünk, mindkét eredmény alapján sárgaréz:

1. pont: $87 \%$ réz és $5 \%$ cink, $7 \%$ oxigén, ez kb. $95-5 \%$-os ötvözetnek felel meg.

2. pont: $84 \%$ réz és $6 \%$ cink, $7 \%$ oxigén, ez kb. $93-7 \%$-os ötvözetnek felel meg.

A zsinór fémfóliája nagymértékben korrodált az oxigén valamilyen réz-oxid vegyületre utal.

\section{A fém anyagvizsgálatok összefoglalása}

A feltételezett aranyozás vagy ezüstözés egyik szálon vagy flitteren sem volt kimutatható. Mindkét párta csipkéje és a flittereket tartó sodrott szálak is sárgaréz fóliával borított fonalból készültek. A „Szám nélküli” sír pártájánál a keretező, sodrott zsinór alacsonyabb cinktartalmú, a hálócsipke fonalának magasabb a cinktartalma, de mindkét minta nagyon korrodált volt, ezért ez az ötvözetarány nem tekinthető az eredeti aránynak. Hamis aranyfonalnak ${ }^{12}$ is szokás nevezni a sárgaréz fóliával készült fonalakat. A flitterek mindkét pártán vékony sárgaréz lemezből készültek.

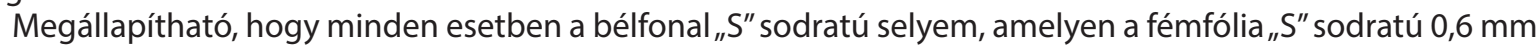
széles sárgaréz szalag. Ez tekinthető alapfonalnak, amelyet mindkét párta csipkéjéhez használtak. Ugyanilyen fonalat használtak a flitterekhez, úgy, hogy „S" sodrat irányban összetekertek két szálat. Pontosabban egy kis fémkarikába fűzték, és úgy sodorták össze. A pártát keretező zsinór is nagyon hasonló. Bélfonala "S" sodrat irányú selyemfonal, amelyből 5-6 szálat tekertek be „Z" sodrat irányban a fémfonallal, majd ebből a vastagabb zsinórból kettőt összesodortak ugyancsak "Z" sodrat irányban. Ehhez a fémfonalhoz használt fémszalag keskenyebb, 0,5 milliméter, a többi esetben 0,9 milliméter.

A zsinór kivételével a fonalak olyannyira egyformák, hogy feltételezhető, hogy ugyanott készülhettek, ha a párták nem is. A párta korai voltára utal a selyem bélfonál használata, mert később a sárgarézhez olcsóbb len-, kender bélfonalat használtak és csak az ezüst, aranyozott ezüst vagy arany fóliákhoz használtak selymet.

\section{Készítés-technika}

A két pártánál a fonalak és a flitterek olyan hasonlóságot mutatnak, hogy a készítésüket nem választom külön.

A párták alapjául szolgáló bőr- és textilanyagok oly mértékben roncsolódtak, hogy csak analógiák alapján feltételezhetjük milyen lehetett. Így ezek készítés-technikájáról részletesen nem írok. Egy vászonkötésú textildarabka maradt meg a "Szám nélküli" párta hálócsipkéje alatt, ahol egyértelműen azonosítható a szövés, de a szálak szerkezete már annyira roncsolódott, hogy nem lehetett azonosítani az anyagát (len, kender vagy selyem...). Ugyancsak a „Szám nélküli" párta keretező zsinórja alatt maradt meg egy kis darab szövet, ami egyfajta bordás jelleget mutat, de olyan mértékben károsodott, hogy sem kötéstípusát, sem anyagát nem lehetett meghatározni. Esetleg egy bársony hátoldala lehetne, de ez nagyon bizonytalan.

\section{A fémfonalak készítése}

A bélfonál selyemből készült. A selyemhernyó gubójáról úgy tekerik le a szálakat, hogy a sok, hajszálnál is vékonyabb szálat egybe fogják. Amint legombolyítják rögtön egy szállá is sodorják.

12 Járó 2010. 65 
KÉT 16. SZÁZADI FÉMFONALAS PÁRTA ANYAGVIZSGÁLATA,
KÉSZÍTÉS-TECHNIKÁJA ÉS RESTAURÁLÁSA

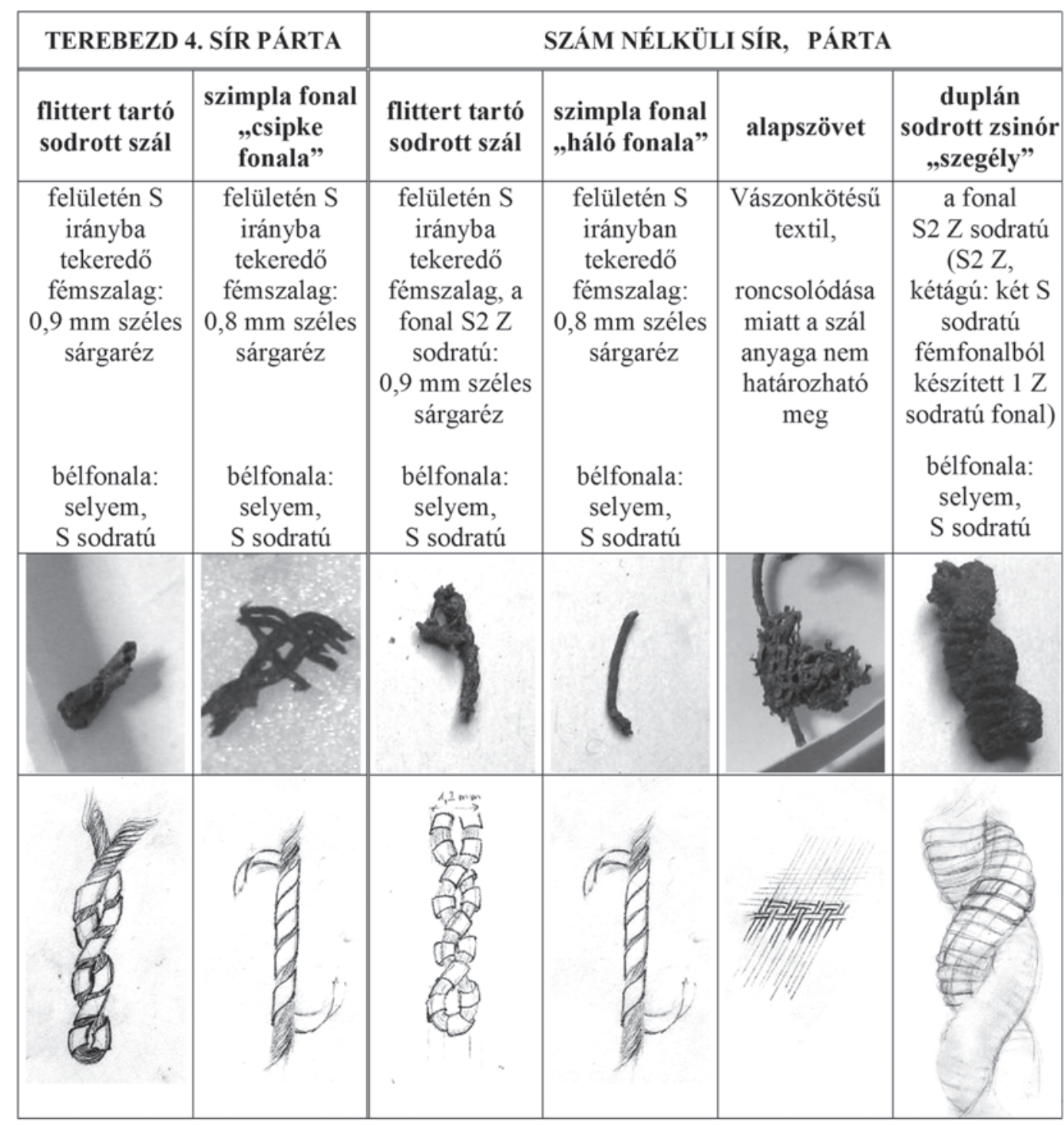

4. kép: Anyagvizsgálatok összefoglaló táblázata, fémfonalak felépitése

A bélfonálra tekerik rá a fémszalagot, amely a fém rugalmasságától illetve merevségétől marad a helyén. Nem találtunk semmilyen ragasztót sem a selyemfonálon, sem a szalag belsején. Használhattak szerves kötőanyagot, de az már nyomtalanul elbomlott.

A sárgaréz, réz (Cu) és cink ( $\mathrm{Zn}$ ) ötvözete. Hagyományosan a sárgarezet rendszerint tégelyekben olvasztják meg. Az előmelegített tégelybe a rezet és cinket váltakozó rétegben rakják be és néha hulladék sárgarezet is kevernek a két fém közé. Végül a betétet a cinkpárolgás megakadályozására szénporral befedik, és a tégelyt a kemencébe állítják. Az olvasztáskor a cink egy része (5-8\%) a legnagyobb elővigyázat mellett is elpárolog, úgy hogy erre számítani kell, ha határozott összetételü ötvözet készítése a cél. A réz és cink aránya szinte bármilyen arányú lehet (1-90\%), attól függően milyen színű ötvözetet szeretnének. A vöröses árnyalattól az aranysárgán keresztül egészen világos, a cink színéhez hasonló is lehet. Hidegen legnyújthatóbb a sárgaréz, ha 15-20\% cinket tartalmaz.

A 0,6 mm széles fóliaszalagok készülhettek vékony lemezzé, majd bőrlapok között vékony fóliává kalapált sárgaréz lapok felszeletelésével vagy vékony dróttá húzott ${ }^{13}$ fémszálak szalaggá hengerlésével.

A fóliakészítés a középkorban kalapálással történt. A megolvasztott fémet lapos formákká öntik, majd ezt kezdik kalapálással vékonyítani. A kalapálás során a fém egyre keményebbé ridegebbé válik, ezért többször

13 A húzás hidegalakítás, egy kúp alakú szerszámon áthúzva, egyre kisebb keresztmetszetủ, és egyre hosszabb darabot kapnak. A dróthúzás mindig több fokozatban történik, lehet szálanként vagy hosszabb drót esetében csévélve. Minden vagy minden második húzás után lágyítani kell, mert a fém felkeményedik. 


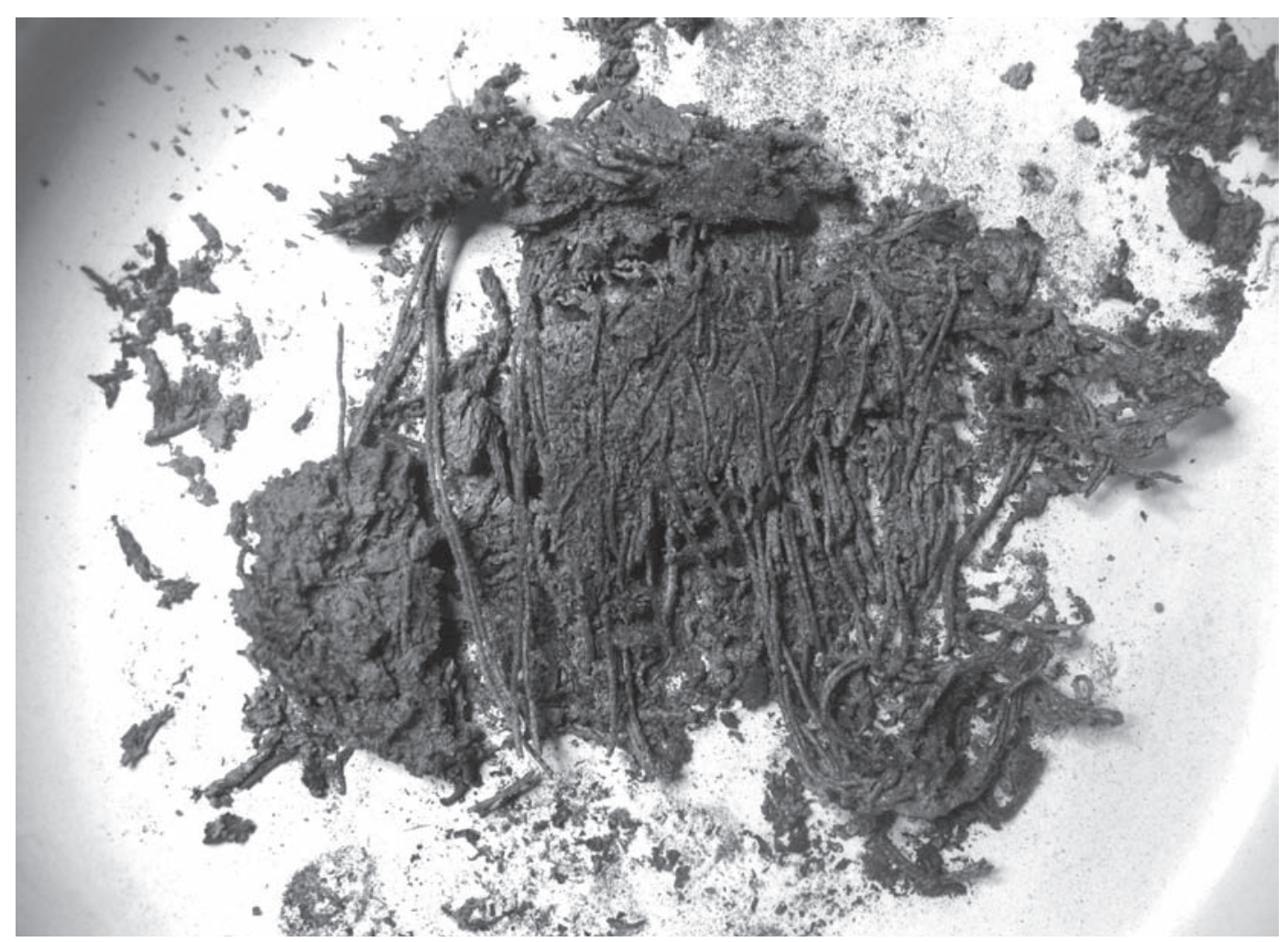

5. kép: „Szám nélküli” párta, hálócsipke hátoldala, tisztítás közben

ki kell lágyítani ${ }^{14}$, hogy újra nyújtható, alakítható legyen. Az ütések hatására a fém rácsszerkezete torzul, majd hő hatására a rácspontokban ülő atomok élénk rezgése visszarendezi a rácsszerkezetet, újrakristályosodik. A lágyítás során a fém nem olvad meg, alakváltozás nem történik.

Kb. 1-0,5 mm-es vastagság elérése után a tenyérnyi lemezeket, vagy fóliákat bőrlapok közé helyezik, felváltva több rétegben. Így kalapálják, vékonyítják tovább ameddig a szükséges fólia vagy füst vékonyságot elérik. Feltételezhető, hogy nem egyenként vágták a szalagokat, hanem valamilyen több pengéjű vágószerkezettel.

A drótkészítéshez a megolvasztott fémet rúdformákká öntik és egyre kisebb keresztmetszetű nyújtóhengerek között vékonyítják. A további vékonyítást (keresztmetszet csökkentést) húzóvason történő áthúzással érik el. A húzóvas vagy húzókő egyre kisebb keresztmetszetű, kónuszosan szűkülő, kúpos belső felületű lyukain keresztülhúzva egyre vékonyodik a drót. Anyagveszteség nincs, mert egyre hosszabb és egyre vékonyabb lesz a drót. A húzások között vörös-izzásig történő hevítéssel lágyítani kell a drótot. Ahhoz, hogy a tényleges húzás előtt a darab elejét át lehessen füzni a szerszámon, azt meg kell hegyezni, kalapálással vagy reszeléssel lehetséges.

Nem bonthattam szét a hosszú fonalszakaszokat a párta túl töredékessége miatt. A szétbontás során megállapítható lett volna, hogy rövidebb fémszalagokkal vannak-e borítva (felszeletelt fóliák) vagy hosszabb szalagokkal (hengerelt drót). Rekonstrukció készítésekor össze lehet majd vetni melyik készítési mód esetén hasonlít jobban a fémfonál az eredetihez. A sárgaréz hidegalakíthatósága, nyújthatósága $20 \%$ cink tartalom alatt jó, a pártákhoz használt sárgaréz ennek megfelel, így alakíthatták. A hengerelt drótból készített fémszalagot stabilabban fel lehet tekerni a bélfonálra és hatékonyabb a készítése.

A flittereket vékony sárgaréz lemezből készítették. A csepp alakú flittereket feltételezhető, hogy nem egyenként vágták ki, hanem egy csepp formájú vágószerszámmal sorozatban gyártották. Erre utal a szabályos, egyforma alakjuk. A felfüzésre szolgáló lyukat egy hegyes szerszámmal kiszúrhatták, üthették, nem pedig fúrták, legalábbis a hátoldalon lévő sorja erre utal.

14 Lágyítás alatt azt a hőkezelést értem, amikor hő hatására a fém kristályos szerkezete visszarendeződik, a hidegalakítás miatt kialakult belső feszültség részben vagy teljes egészében megszünik. Általában vörös-izzásig melegítjük, minél vékonyabb a lemez vagy drót annál óvatosabban nehogy megolvadjon. 


\section{A Tapsony-Terebezd 4. számú sír párta készítés technikája}

Az alapszövet, amelyre a csipkét helyezték, több rétegű lehetett. Alul bőr vagy textil, amit egy bársony szalag boríthatott. Lehet, hogy a két réteg közé valamilyen növény rostos szálaiból merevítést varrtak, de ez nem volt egyértelmú, annyira roncsolódott a hordozó. A földes, gyökerekkel átszövődött párta bontásakor nem lehetett egyértelműen megállapítani. (A szám nélküli pártánál igen egyértelműen látszik, hogy növényi rostokkal tömték ki az ívesen kiemelkedő vastag részeket.)

A csont- és üveggyöngyök mérete hasonló, formája kissé eltérő a készítés módjából adódóan.

Az üveggyöngyök zöld és sárga színben készültek (17+8). A csavart üveggyöngyök közül 1 sárga és 5 zöld. Az üveget zöldre és sárgára színezték. ${ }^{15}$

A gyöngyök formája arra vall, hogy az üveget megolvasztás után 2-3 milliméter vastag szállá húzták és egy csőrre vagy rúdra tekerve alakították ki a gyöngyszemeket. A kis gyöngyöket egy kis karikából alakították ki, a csavart gyöngyöknél többször spirálisan tekerték fel az üvegszálat, így kialakítva a hosszúkás gyöngyöt.

A csontgyöngyök (17 db) a fémfonalak korróziós termékeitől zöldes, barnás, vöröses árnyalatúra színeződtek. A csontgyöngyök kissé kónuszos formája és a kb. a harmadánál körbefutó kis perem esztergályozásra utal. Hasonló módon készültek a csontgombok is.

A liliomos vagy tulipános középdísz vékony lemezből készült. A lemez a flitterekhez hasonlóan készülhetett. Sem a kidomborodó minta széleinél, sem a formák találkozásánál nem lehet poncoló nyomait felfedezni, sem cizellálásra utaló jeleket. A lemez vékonysága is arra vall, hogy préseléssel készült. A présforma két részből állhatott, egy pozitív és egy negatív mintából és a két forma között akkora méretkülönbségnek kellett lennie, amilyen vastag lemezből tervezték préselni. A pénzveréshez hasonlóan két présforma közé kell helyezni a kilágyított lemezt és kalapáccsal leütni.

\section{A csipke készítése, a díszítés jellemzői}

A párta alapszövetén 2 centiméter szélességben egymástól háromágú sodrott fémfonal keret fut végig, közötte széltől-szélig érő fonott vert csipke. A csipke - a 16-17. században általános - korai ún. fonott/fonatolt vert csipkék típusába tartozik. Mintája rendkívül egyszerű: a két szélső 1,5-1,5 párat 2 pár köti össze cikk-cakk vonalban. Érdekessége a páratlan számú szálvezetésben rejlik, mert a vert csipke alapvetően páros számú fonallal készül. A csipkét a sodrott szélhez a tǔzéspontokba vezetett átfogó öltésekkel utólag rögzítették össze. A rögzítő- és a bélelő szálak már elporlottak, de mivel a fémszál merev, ezért a csipke formája megmaradt.

A párta különlegessége, hogy a központi tulipándísz mellöl két irányba indul a csipke, így a tulipán mellett mindkét oldalon egy-egy kezdőpont található. Mivel a baloldal csipkevégpontja is megmaradt a leletanyagban

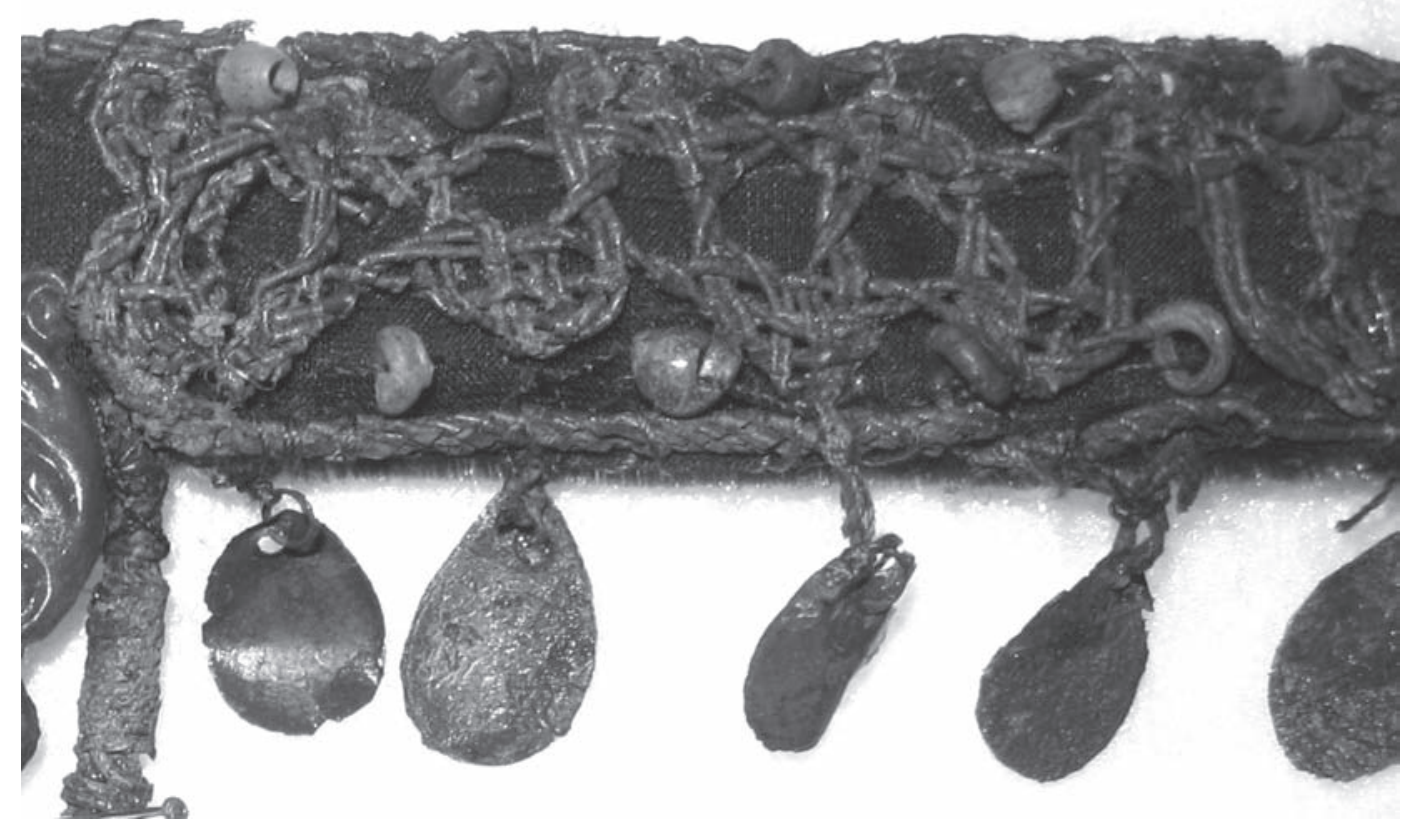

6. kép: A Tapsony-Terebezd 4. számú sír, párta részlete (középröl jobbra eső kezdőrész)

15 Az üveggyöngyök anyagösszetétel vizsgálatára nem került sor. 
- a negyedik hiányzik -, ezért ez is alátámasztja, hogy nem karikapártáról, hanem hátul nyitott, állítható elő pártáról van szó. Mivel ez a végpont letört a csipkéről, így nem állapítható meg pontosan, hogy mekkora lehetett az egyik oldal, ezért nem tudjuk kiszámolni a párta hosszúságát sem.

A csipke széleihez erősítették a csepp alakú islógokat, az alsó széléhez kis karikával (bouillon drótból levágva), a felső széléhez pedig hosszú, öszszesodort sárgaréz fonallal, így kb. egyforma hosszúságban, sűrűn egymás mellett díszítették a homlokot. A csipkék tűzéspontjaiba rögzítve helyezték el az üveggyöngyöket, melyek bemélyedése megfelelő foglalatot adott az üveggyöngyöknek és a felső sor islógos díszítésének rögzítését is takarta. A tulipán két oldalát két hosszú csavart, gyöngyös végű fémszál hangsúlyozza ki.

A párta formája, a csipke, a díszítés és az alapanyag alapján a 16. század második felére - 17. század elejére datálható. Ez a fajta kezdetleges, fémszálas fonatolt vert csipke rendkívül népszerű volt a 16. század közepétől kb. egy századon keresztül. Európa-szerte ismerték és használták ezt az egyszerű technikai és formai megoldást keskenyebb és szélesebb kivitelben egyaránt. A gazdagabbak húzott vagy hengerelt aranyozott ezüst vagy ezüst szálból, vagy selyembélelő szálra tekert fémszálból ${ }^{16}$, a kevésbé tehetősek hamis fémfonalból, rézszálból vagy len fonalra tekert változatából készültek. A fémszálból készült csipkék legyenek azok egyszerủbb vagy bonyolultabb kivite-

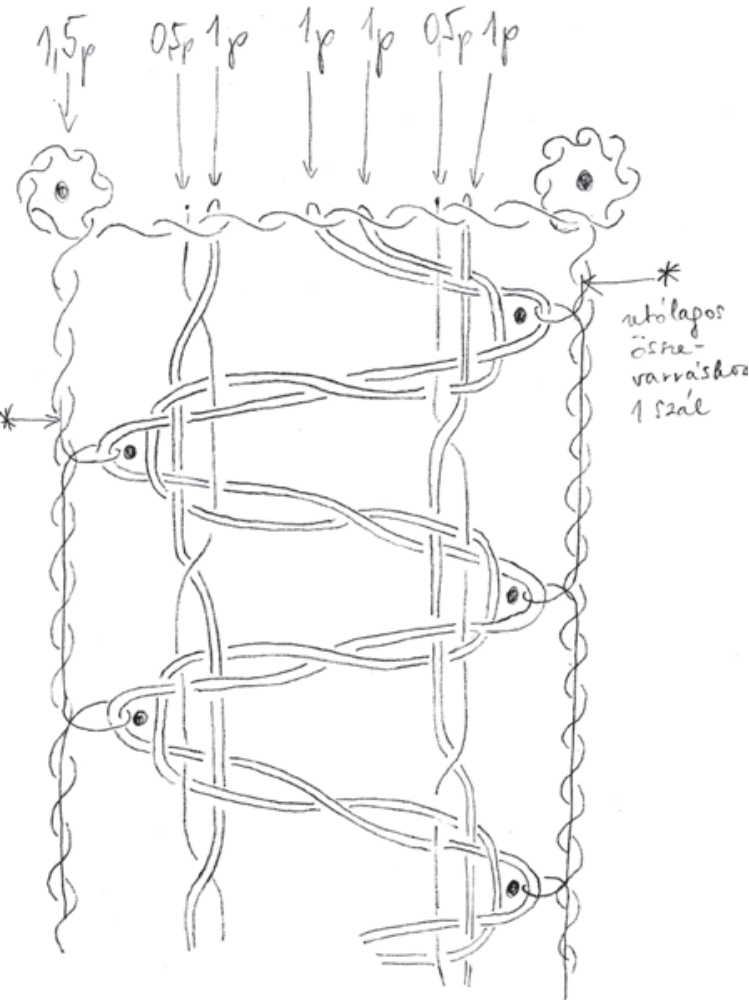

7. kép: A Tapsony-Terebezd 4. számú sír, párta csipkéjének mühelyrajza (A rajzot Erdei T. Lilla készítette) lúek - másként viselkednek, mint len- vagy selyemfonalból készült változataik. A fémcsipkék merevebbek, jobb tartásúak, kevésbé deformálódnak. Számos európai viseletben megtalálhatóak ún. elegyes, azaz arany-ezüstfonalas, gyöngyös, islógos díszítéssel. Ilyen fémcsipkéket hordtak a nyugat-európai udvarokban, de ismertek a dán uralkodóházból ${ }^{17}$, a svéd királyi udvarból és egyházból ${ }^{18}$ is, de Bulgária területén is feltártak hasonló csipkéket. ${ }^{19}$

\section{A „Szám nélküli” sír párta készítés technikája}

\section{A „Szám nélküli" sír párta csipkéjének készítés technikája}

A párta középső gyöngyös díszítését keskeny, ún. hamis (réz-cink alapú) aranyfonalból készült vert csipke keretezi négyszög alakban. A vert csipke - a 4. sír pártáéhoz hasonlóan - a 16-17. században általános korai ún. fonott/fonatolt vert csipkék típusába tartozik. Keskeny, 2 párral készült, díszítését csupán a kitűzése, a pikó adja.

A középvonaltól két oldalra egy-egy kidudorodó, téglalap alakú rész fut két oldalra, a tarkó irányába, ahol a két fél összeért. Ezen a kidomborodó részen van a fémszálból készült csipkeszerű, dupla szálas „lebegő hímzés”, aminek csak a szélei vannak beleöltve a textilbe. Mintája töredékessége miatt nagyon nehezen kikövetkeztethető. Érdekessége, hogy M $\mathrm{N}$ alakban van kifeszítve az alapszál és abba kapcsolódik hurkosan (szintén dupla szálas) a „díszítőszál". Ezt díszítette még - a töredékekből kikövetkeztethetetlen csipketextúrára emlékeztető textil (cikk-cakk alakú fonott típusú fémszálas csipke?). ${ }^{20}$

16 Járó 2010.

17 Kruse et al.1988.

18 Dahrén 2010.

19 A csipke készítés-technikai bekezdését Erdei T. Lilla muzeológus-etnográfus készítette. A pártát restaurálás közben és restaurálás után vizsgálta. A feltárás utáni állapotot fotódokumentáció alapján vizsgálta.

20 A csipke készítés-technikai leírását Erdei T. Lilla készítette. A pártát restaurálás közben és restaurálás után vizsgálta. A feltárás utáni állapotot fotódokumentáció alapján vizsgálta. 


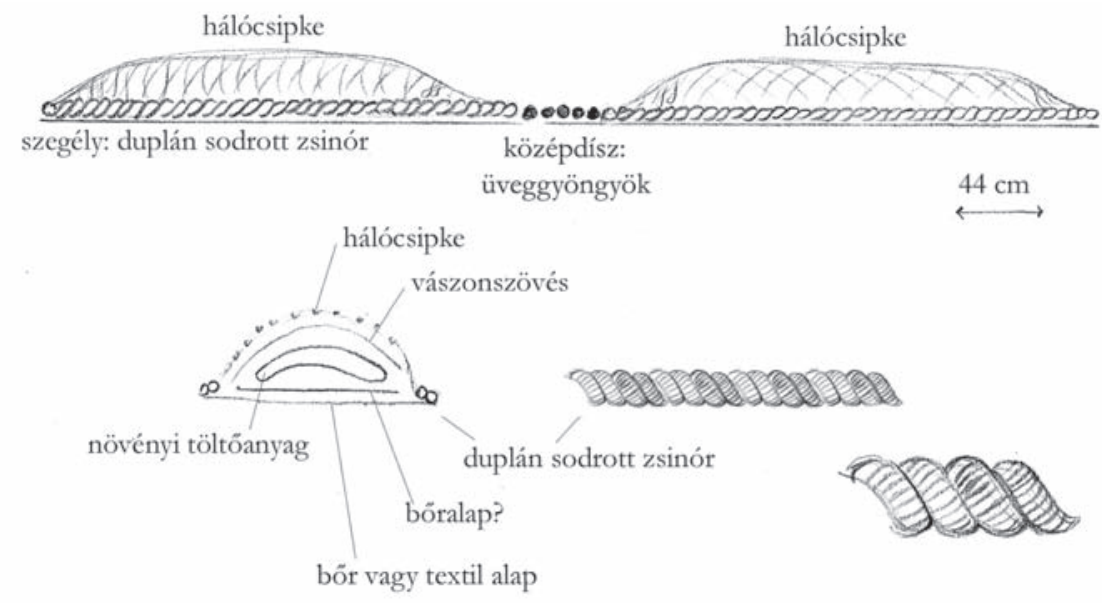

8. kép: A „Szám nélküli” sír, párta szerkezeti rajza

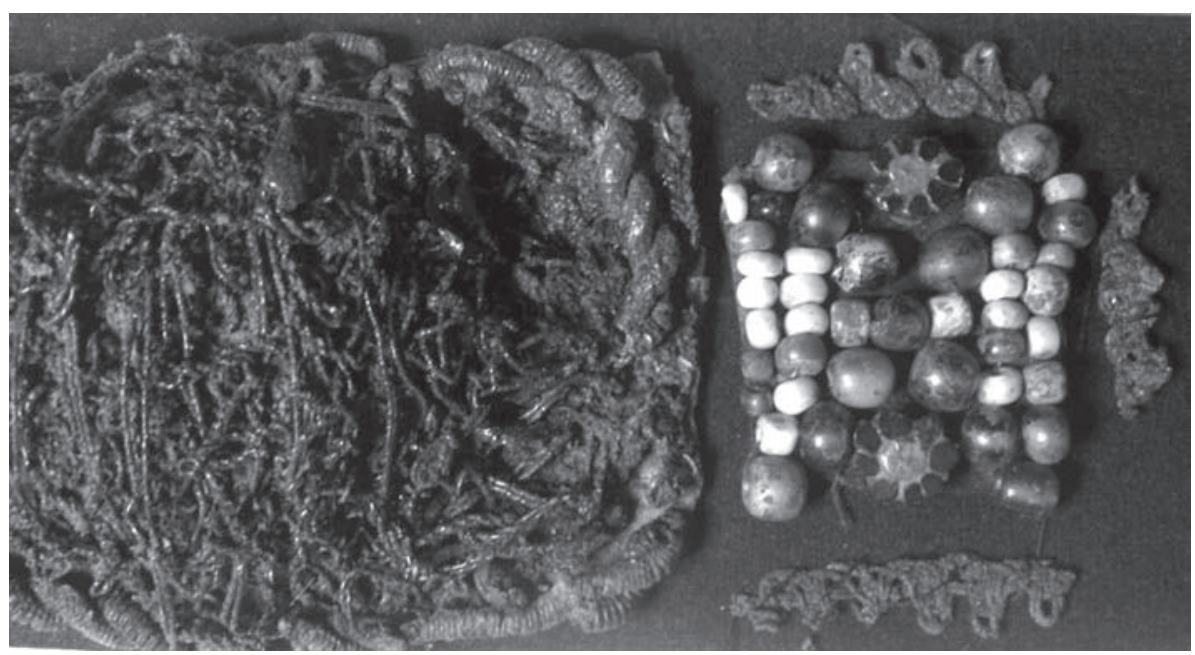

9. kép: A „Szám nélküli” sirr, párta üveggyöngyös középrésze és a keretező csipke, restaurálás után

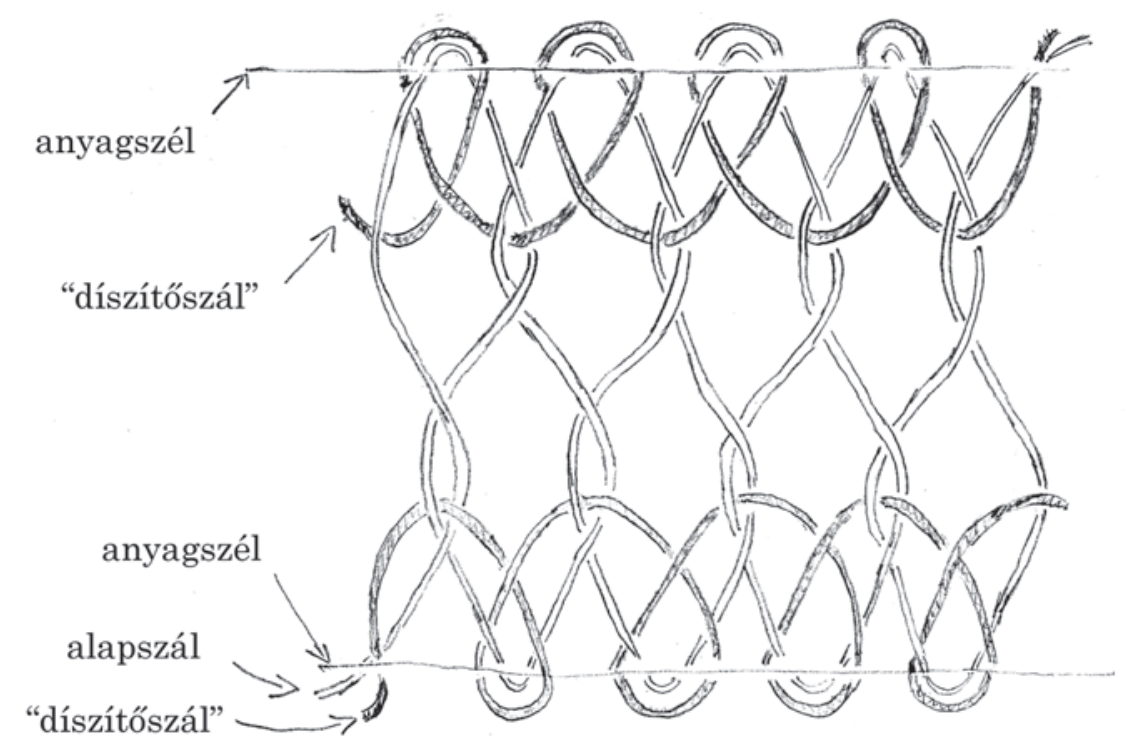

10. kép: A „Szám nélküli" sír, a párta „lebegő hímzés" mühelyrajza (A rajzot Erdei T. Lilla készítette) 


\section{A Tapsony-Terebezd 4. számú sír pártájának restaurálása}

A restaurálás nehézségét az okozta, hogy a párta különböző anyagai különböző mértékben károsodtak, illetve bomlottak le. Az eltérő anyagok kezelése, konzerválása más-más eljárást igényelne. Mivel a pártát alkotó anyagok nem választhatóak el egymástól, pl. fémekre és szerves anyagokra, ezért egyszerre kell megoldani a kezelésüket. A bontás, tisztítás során úgy kellett megoldani a rögzítést, az alátámasztást, átitatást, hogy közben a földes rárakódásokat, megkeményedett homokos részeket apránként el lehessen távolítani.

A tisztítás és konzerválás általában két elkülöníthető munkafázis, de itt a párta rendkívül meggyengült állapota miatt, szinte egyszerre kellett átitatni és tisztítani.

A korrodálódott fém részek miatt a nedvességet, a vizes tisztítást kerülni kellett, de szükséges volt a megkeményedett földet puhítani. A nagymértékben roncsolódott szerves anyagokat is óvni kellett. Szilárdításra volt szükség, az átitatás Paraloid B72 acetonos oldatával történt. A nedvesítés alkoholos ecseteléssel történt, így nem oldódott vissza az acetonos átitatás.

A fémfonálból készült átitatott csipke egy merevített bársonyszalagra lett rögzítve varrással. Az átitatás során egy vékony védőréteg is kialakul a fém felszínén, ami megóvja a nem szélsőséges mértékú légnedvesség és egyéb levegőben lévő korróziót okozó anyagok káros hatásaitól. ${ }^{21}$

A flitterek külön szálra kerültek, azért, hogy a bársonyra rögzített fémfonalas csipke minél kevésbé sérüljön a további varrás során, és azért is, mert a flitterek elrendezése csak feltételezés. Az egyben maradt kis töredék alapján nem egyértelmű, milyen sorrendben és milyen sűrűn voltak a flitterek. Feltételezhető, hogy egy karikán egy flitter, illetve egy karikán két flitter volt váltakozva. Ezek egymáshoz képest előrébb és hátrébb, két sorban, kicsit lejjebb ill. följebb helyezkedhettek el.

Egy szálra, egyesével egy másik szálra kettesével lettek felfúzve. (Az eredeti töredéken maradt egy flittertartó karikán függő flitter pár és egy másik, aminek az eredeti helye nem ismert). A felfüzött flitterek néhány öltéssel lettek rögzítve ezért, ha másmilyen elrendezésre kerül analógia könnyen lebontható és átfűzhetőek a flitterek.

A flitterek alátámasztása üvegszövettel, ragasztása PVB-vel ${ }^{22}$ történt. A kiegészítések retusfestése földfestékekkel és bronzporral készült, a kötőanyag PVB. A 85 db flitter közül 47 db igényelt alátámasztást, kiegészítést, retusálást.

A szerves pártarészek (növényi maradványok és bőrmaradványok) szilárdítását Paraloid B72 oldatával23, többszöri bemártással lehetett megoldani.

A párta és minden darabja habkartonnal bélelt dobozba kerültek. A töredékek formájukat követő mélyedésekbe lettek ágyazva, hogy minél inkább védve legyenek.

Így a leletek a további sérülésektől a lehető leginkább megkímélve tárolhatók, együtt tarthatók, kutathatók, kiállíthatók.

\section{A „Szám nélküli" sír párta restaurálása}

A párta átvételekor az alsó rész japánpapírral volt alátámasztva és részlegesen át volt itatva Paraloid B72vel. A középső, gyöngyös rész megtisztítva a japánpapírhoz volt varrva, pontosan az eredeti helyzetének megfelelően.

Az alátámasztás és a fémszálas hálócsipke között földréteg és feltételezhetően bőr és növényi maradványok vannak.

Kétoldalt összehúzódott, csavarodott felpúposodott. A középső rész kevésbé deformálódott, feltételezhető, hogy ott a gyöngyös rész nem engedte annyira zsugorodni a bőrt, és ott nem volt a kitömött vastagított bélés. Eredeti szélesség a középrész méretéből következtethető.

A szélén körbefutó duplán sodrott zsinór a rövidebb oldalakon is megvan, kb. olyan hosszan, mint a középdísz szélessége, ami zárja a hálócsipke széleit. Csak feltételezhetjük, hogy hátrafelé fémfonalas díszítés nélkül folytatódhatott a bőr vagy textil rész vagy esetleg szalagokkal. Fémcsat, kapocs vagy akasztó nem volt, ami a záródást biztosíthatta volna.

A párta alapjául egy 40 centiméter hosszú, 8 centiméter széles fátyolanyaggal borított, 3 rétegben összeragasztott ${ }^{24}$ üvegszálas szövet készült, ami elég tartást biztosít a töredékek stabil alátámasztásához.

A párta rossz állapota miatt a restaurálást az egyes részeken külön-külön, több szakaszban lehetett elvégezni. A különböző részek másképp károsodtak, zsugorodtak, több darabra töredeztek. A restaurálást öt egységre bontottam.

21 Fontos az állandó hőmérséklet és páratartalom biztosítása, kiállításban és raktárban is. A hőingadozás fokozza a védőbevonat öregedését, repedezetté válhat és páralecsapódást okozhat a mütárgy felületén.

22 Poli-vinil-butirál 15\%-os, alkoholos oldatával.

23 Metil-akrilát és metil-metakrilát kopolimer $5 \%$-os acetonos oldata.

24 Poli-vinil-butirál $15 \%$-os, alkoholos oldatával ragasztva, majd száradás után vasalással rögzítve. 
A középső gyöngyök a japánpapírral együtt kerültek az új alapra, mert a varrás stabilan tartott, és feltételezhetően pontosabban őrzi az eredeti elrendezést, mintha lebontás után újra varrásra kerül.

A bal szélső negyed annyira deformálódott, hogy szükséges volt a bontás. Először a szegélyező zsinórdarabok kerültek lebontásra. Több órás alkoholos áztatás után leemelhető volt a hálócsipke rész.

Óvatos ecseteléssel a földes homokos berakódások egy része eltávolítható volt. A további tisztítás olyan mértékben károsította volna a nagyon töredezett szálakat, hogy inkább a maradék homokkal együtt került átitatásra. Az átitatás ecsettel és csepegtetéssel történt, alkoholban oldott poli-vinilbutirál 3\%-os oldatával. A leemelt hálócsipke egy domború alapra lett fektetve, aminek a formája a feltételezett növényi részekkel kitömött bélés formájának felelt meg. A domború alap, amire a hálócsipke került poliuretán habból faragott, múszálas anyaggal bevont forma, amely az alaphoz lett varrva. A hálócsipke a szegőzsinór és szegőcsipkék is varrással kerültek rögzítésre.

A bal oldali rész közepén - ahol eltörött - látszott a párta keresztmetszete, a hordozó alap réteges szerkezete. A pártaöv több rétegből állhatott. Egy textilborítású bőr lehetett az alap, amelyen egy vászonkötésű textil vagy bársonyborítás volt. Ezt a „borítást" kétoldalt a középrész jobb és bal oldalán növényi törettel tömték ki, amely egy 1,5-2 centiméter magasságú, hosszúkás a széleinél ellaposodó forma lehetett.

A baloldal jobb széle kevésbé deformálódott. Ez a rész egyben lett konzerválva, hogy minél többet meg lehessen őrizni az eredeti szerkezetből. Ecseteléssel kezdődött az átitatás, hogy a pergő részek egyben maradjanak, majd az egész negyed töredéket egyben bemerítéssel itattam át. Addig maradt az oldatban, ameddig a felszálló buborékok képződése abba nem maradt.

A jobb oldali rész két részletben került bontásra, hasonló módon, mint a baloldal jobb oldali része.

A párta összes töredéke egy habkartonnal bélelt dobozba került.

A párta részei az eredeti helyzetüknek megfelelően kerültek rögzítésre. Az alsóbb rétegekből kikerült töredékek a helyzetüknek megfelelően a párta alatt lettek elhelyezve. A bontás szerinti eredeti sorrendjük szerinti elrendezésben és sérülékenységük miatt polietilén habba mélyített, a töredékek formáját követő mélyedésekbe lettek ágyazva.

A leletek így a további sérülésektől a lehető leginkább megkímélve tárolhatók, együtt tarthatók, kutathatók, kiállíthatók.

\section{Összefoglalás}

A két párta restaurálása közben tett megfigyelések, és az anyagvizsgálatok eredményei alapján rekonstruálhatóvá vált a párták készítésének majdnem minden lépése.

Bár a két párta más típusú, de a fémfonalak morfológiájának hasonlósága, egyezése arra enged következtetni, hogy a fonalak ugyanott készülhettek. Mindkét csipke selyem bélfonálra, S sodrat-irányban tekert sárgaréz fóliával borított fonalból készült, melyek vastagsága is megegyezik. A sárgaréz fólia szélessége csak egy-két tized milliméteres eltérést mutat és a sárgaréz anyagösszetételében is minimális az eltérés. Mivel több a hasonlóság, mint a különbség és kézmúves technológiával gyártott fonalról van szó, ezért akár azt is feltételezhetjük, hogy a fonalak ugyanonnan származhatnak. Ritkaságnak számít, a sárgaréz és selyem párosítása, ugyanis később a selyem bélfonálhoz már nemesfémeket használtak.

A párták nagyon rossz állapota (sérült, deformálódott, korrodált) ellenére a restaurálás során készült alapos dokumentáció lehetővé teszi mindkét párta pontos másolatának elkészítését. A 4. számú sír pártáját díszítő csipke típusa egyértelműen meghatározható volt, így rekonstruálható is. Az ismeretlen lelőhelyű, szám nélküli párta szerkezete és felépítése jobban meghatározható. Csipkéje rosszabb állapotú, de rekonstrukció készítése erről is lehetséges. 


\title{
Materialuntersuchung, Herstellungstechnik und Restaurierung der zwei Jungfernkränze mit Metallfaden aus dem 16. Jh.
}

\author{
BOGLÁRKA LENGYEL
}

Aufgrund von Beobachtungen der Restaurierung der 2 Jungfernkränze und aufgrund der Ergebnisse der Materialprüfungen konnten fast alle Schritte der Herstellung der Jungfernkränze rekonstruiert werden.

Obwohl die 2 Jungfernkränze andere Modelle sind, lässt sich durch die Ähnlichkeit der Fäden eine Übereinstimmung der Morphologie der Metallfäden erschließen, dass sie ebendort hergestellt wurden. Beide Spitzen wurden auf einen Hauptseidenfaden aus S-Draht gewundeten mit Messingfolie verkleideten Fäden hergestellt, die gleich stark sind. Der Unterschied der Breite der Messingfolien ist nur 0,1-0,2 mm und auch in der Materialzusammensetzung des Messings ist der Unterschied minimal. Da es mehr Ähnlichkeiten als Unterschiede gibt und es geht schließlich um handwerklich hergestellte Fäden, kann man annehmen, dass die Fäden von demselben Ort stammen. Es ist eine Rarität Messing und Seide zu verbinden, denn später wurden Edelmetalle zum Hauptseidenfaden benutzt.

Trotz des sehr schlechten Zustandes der Jungfernkränze (verletzt, deformiert, gerostet) lässt sich durch die, während der Restaurierung gründlich geführten Dokumentation die Kopie der beiden Jungfernkränze pünktlich herstellen. Der Typ der Spitze, die den Jungfernkranz des 4. Grabes schmückt, konnte eindeutig bestimmt und so auch rekonstruiert werden. Die Struktur und der Aufbau des anderen Jungfernkranzes, der keine Zahl hat und von einem unbekannten Fundort stammt, ist besser zu bestimmen. Seine Spitze ist im schlechteren Zustand, trotzdem kann man ihn auch rekonstruieren.

\section{Irodalom}

Bárdos E. 1987.: Középkori templom és temető Kaposvár határában II. Somogyi Múzeumok Közleményei 8. 5-82.

Dahrén, L. 2010.: Med kant av guld och silver. En studie av knypplade bårder och uddar av metall 1550-1640. Uppsala Universitet, Uppsala

Gábor G. 1996.: Középkori párták Békés megyében. Móra Ferenc Múzeum Évkönyve - Studia Archaeologica Il. 381-401.

Járó M. 2010.: Fémfonalak az Esterházy-gyűjtemény textíliáin. In.: Pásztor Emese (Szerk.): Az Esterházy-kincstár textíliái. Iparművészeti Múzeum, Budapest, 56-66.

Kruse, A. et al. 1988.: Fru Kirstens børn. To kongebørns begravelser i Roskilde Domkirke. Nationalmuseet, Poul Kristensens Forlag, Herning

Mojzsis D.1984.: XVI-XVII. századi női fejdíszek a nagylózsi leletanyagból. Folia Archaeologica XXXV. 185-212.

Selmeczi L. 2006.: „... Istentül adattál édes szűz koronám”. Adatok a párta történetéhez a Kárpát-medencében. Ethnographia 117. 17-63. 